\title{
Ancient Inventories of Goods Belonging to the Parish Church of St. Margaret Pattens in the City of London
}

By W. H. St. John Hope M.A., F.S.A.

To cite this article: By W. H. St. John Hope M.A., F.S.A. (1885) Ancient Inventories of Goods Belonging to the Parish Church of St. Margaret Pattens in the City of London, Archaeological Journal, 42:1, 312-330, DOI: 10.1080/00665983.1885.10852179

To link to this article: http://dx.doi.org/10.1080/00665983.1885.10852179

曲 Published online: 15 Jul 2014.

Submit your article to this journal $\pi$ 
ANCIENT INVENTORIES OF GOODS BELONGING TO THE PARISH CHURCH OF ST. MARGARET PATTENS IN THE CITY OF LONDON.

By W. H. ST. JOHN HOPE, M.A., F.S.A.

Amongst the records of the parish church of St. Margaret Pattens, in the city of London, is a folio volume in the original stamped leather covers (very badly mended recently), measuring 15 inches by 12 inches. By the kindness of the Rev. J. I. Fish, the present rector, I have been allowed to examine this volume. It now contains thirty folios, but a very large number have been destroyed, and of the remainder sixteen folios and three pages are blank. From the internal evidence of omissions and mis-spellings it is clear that the entries were transcribed into the book.

The following is an abstract of its contents, but the inventories I have transcribed in full.

Folio 1 is lost.

Folio 2 commences

In the name of the Holie Trinite our blissed lady his moder Seint Margarete virgyn and Martir and all Seintis / Sir Water Muschamp pson of the parissh Chirche of Seint margaretes Patyns in london John Wilson Barbour and John Dounton Peautrere Wardeins of the Chirche in the holy feest of Ester The yere of our lord god $M^{1}$ CCCC lxx and the $x^{\text {th }}$ yere of the reigne of Kyng Edward the fourth with thassent of all the parisshens of the same Chirche Aggreed and Assented that all the evidences concernyng or touchyng the londes rentes and Tenementis of the said Chirche shall be entiteled in this booke ceriately to a ppetuett memory for theym and their Successours Which folowen hereafter that is to sey.

Then follow transcripts of

(1) Deed by which Ralph de Coventre rector demises to Thomas de Wrasle a tenement with houses thereon, for a yearly rent of $15 \mathrm{~s}$. (Undated, but John le Blund, then mayor, occurs among the witnesses.) 
(2) Will of Isabell Carpenter, formerly the wife of Symon de Canterbury, 1342. Her body to be buried in the cemetery of St. Margaret Pattens, near the sepulchre of the aforesaid Symon. Bequests of money to the high altar for the souls of John and Matilda her parents, Thomas Richard and Symon her husbands; for the sustentation of a light before the cross in the church, etc., etc.

(3) Memorandum of proof of will January 2, 1343.

(4) Fourteen memoranda concerning deeds relating to parish property.

(5) Incomplete copy of a memorial concerning certain encroachments of waterfall and lights.

These occupy most of folios 2 and 3.

Folios 4, 5, and 6a contain an inventory of goods, jewels, and ornaments, dated 2 August, 1470.

Folios $6 \mathrm{~b}, 7,8,9 \mathrm{a}, 10 \mathrm{a}$, contain a list of additions made to the church goods and ornaments from 1479 to 1486 , during the tenure of the same two churchwardens.

Folios 9b, 10b, 11, 12, 13, 14, 15 are blank.

Folios 16, 17 and a loose folio of uncertain number contain part of an inventory made in 1511 .

Between folios 17 and 24 five folios are lost.

Folio 24 contains several memoranda, and lists of goods when a period of spoliation prevailed. They are dated 10 Henry VIII. (1518), 1521, 1536, and 1548.

Folios 25 to 34 , and 36 to 188 inclusive, also 193,196 to 201 inclusive, 204 and 205 are missing.

Folios 35, 189 to 192 inclusive, 194, 195, 202, 203, 206, 207a, and 208 are blank.

Folio $207 \mathrm{~b}$ bears a memorandum of 1557 that if any tenant of church property be elected churchwarden, he shall not spend more than $10 \mathrm{~s}$. on the repairs of his house during his term of office without the consent of the vestry.

[f. 4 a.]

This is the Inventary of all the goodes Juelx and Ornamentis belongyng unto the Chirche of Seint margarete Patyns. - made the secunde day of the moneth of August The yere of our lord god MCCCClxx And the $x^{\text {th }}$ yere of the reigne of kyng Edward the fourth that tyme beyng pson Sir Water Muschamp and Wardens John Wilson Barbour and John Dounton Peautrere. 


\section{INVENTORIES OF ST. MARGARET PATTENS, LONDON.}

. Juelx . ffirst a Crosse of silv'e weying $\mathrm{v}$ tb $\mathrm{j}$ unc'.

Itm a Chalice of silv'e Gilt $w^{t}$ a patene weying togider xviij unc'. j qart of an unc'.

Itm $\mathbf{j}$ Chalice of silv'e gilt with the patene weying togider xiij unc'. ${ }^{1}$

Itm a Chalice of silv'e. pcell gilt $w^{t}$ a patene. weying xiij unc' \& di' \& half a qart'

Itm $j$ Chalyce of silv'e $w^{t}$ a patene weying $x x v$ unc' \& di' and half a qart'.

Itm a Cowpe of silv'e. for the sacrament ${ }^{2}$ pcell gilt weying xxviij unc' iij qa't's \& di'

Itm a Sensour of silv'e pcell gilt weying . xxix unc'

Itm a Crismatorye of silv'e weying xiij unc' iij q $q^{a}$ 's

Itm a Relyke of silv'e ou'e gilt set $w^{t}$ stonys and a pece of the holy Crosse therin

Itm an ymage of Saunct' Katerne silv' and gilt

Itm a Mustrante ${ }^{3}$ of silv' pcell gil tby the gifte of $s^{\prime}$ John douton waying lvj unc'

Itm . a Crosse with mary \& John silv' \& gilt of the 'gyft of Richard Bowell \& Elizabeth his wyf weying by Troy Weight lxxxvij unces \& ijj qart'one

(Added in another hand)

Itm ij Candlestyck $\rho$ of sylv' \& pcell gylt w ${ }^{t}$ angelle face in $y^{e}$ mydde of $y^{e}$ Candlestycke

Itm ij sylv' Basyns pcelt Gylt w $w^{t}$ Roses in the mydde of them

Itm a Shyp of Syiv' $w^{t}$ a sylv' spon pcell Gylt $w^{t}$ a lambe $y^{r}$ on | of the Gyfte of Robt [May] and John Wyllson and Johña the wyff of them ${ }^{4}$. the $\mathrm{p}^{\prime} \mathrm{c}^{\prime}$........ v marke

Itm a Senser of Sylv' \& pcell Gylt w ${ }^{t}$ lyberde hede

Itm a Chalyce of 'sylv' \& a patent Cleyn gylt wt a crucyfyx mary \& John in the fote and in the paten an holy lambe.

. Bokes. Itm a masse boke for the high auter principatf

Itm a nother masse boke for our lady Chapeff ${ }^{5}$

Itm an old masse boke unkev'ed.

Itm $\mathbf{j}$ boke called . a pistoler \& Gospeler and a principałf grayłt

Itm a new graytf

Itm an old grayłf

Itm iij new processionaries

Itm an old processionary with a sawter and an Ymner therein

Itm an old ordenall with a processionary therein

Itm a new ymner notyd. ${ }^{6}$

Itm a boke called a lectornall for pryncipałf foeste

Itm a new antiphoner principatt

Itm a new antiphoner secondary

Itm an old antiphoner

Itm a new Colectour.

Itm an old Portoos noted.

Itm a grete sawter

1 This item erased.

2 The pyx in which the Sacrument was hung over the high altar.

3 A monstrance.
4 Query, was she wife to both men?

5 This line erased.

- In the margin "in $y^{e}$ handes of bryt. tayn." 
INVENTORIES OF ST. MARGARET PATTENS, LONDON. 315

Itm a new. legent tempatf

Itm a new legent Sc̈or' (Sanctorum)

Itm ij Sawters chayned in our lady Chapett.

(Added in a later hand).

Itm a Manuell

Itm an old gret portoos notyd.

(In another hand)

It' a nywe p'ssessener' bowt be John spelet \& John mūd) schryche Warddens

(In the same hand as the additions to the list of 'Juelx')

Itm an New Breviatt antyphoner'

Itm j boke for Rectors for matens. masse . \& evynsong.

Itm a complete p'cessyonary

Itm vj queres of $y^{e}$ new fest of $o^{r}$ lady. ${ }^{1}$

Itm $j$ of the masse of Jhus

Itm a psalter | $\mathrm{w}^{\mathrm{t}}$ a Kalendr'

Itm a lyteff portus

[f. 4 b.]

laton and I Itm a Crosse of laton gilt

. Itm an old Crosse of laton gilt

Peautre. Itm a sensour of laton

Itm a shipp of laton

Itm ij grete standards of laton principatf

Itm ij Candelstikkes of laton for the high auter

Itm iij smale Candelstikkes of laton for processions of laton

Itm ij Candelstikkes of laton for our lady Chapelf

Itm an holywater stopp of laton $w^{t}$ a styk ${ }^{2}$

Itm an Offeryng dissh of Coper

Itm an hangyng of laton for the lampe in the quere

Itm an hangyng of laton for all sowlen light in the body of the Chirche

Itm iiij Candelstikkes of Peautre ij grete \& ij smale

Itm iij peir of Crewette of peautre

Itm a bason of peautr' $w^{t}$ iij smatt square bollys for the Pascatt

Itm $\mathrm{xx}^{3} \mid$ tap disshes of peautr'4 for the Rodeloft

Itm a Cowpe of laton to put in the sacrament

Itm a Canape $\mathrm{w}^{t}$ iij Crownys of laton to hang ov'e the sacrament ${ }^{5}$

(Added in a later hand.)

Wch canape was deliv'ed to the pson for the ch'ge he made a new cov'yng ov' the sacrament at his propre cost and the Wardyns Thomas alisaundr' \& John ..... not to be charged with the said canape $\mathrm{w}^{\mathrm{t}}$ ijj crownys

.Copes and. Itm a vestment of rede veluet with dekon subdekon and a Vestemente. Cope / the Orfreys enbrowded $w^{t}$ gold.

Itm a vestement of whyt cloth of Bawdekyn with deken subdekon and a Cope of the same sute of the gift of John Gest the Orphrays of rede damask.

\footnotetext{
1 The feast of the visitation of the blessed Virgin Mary, ordered to be observed by the Council of Basil by decree dated July 1, 1441.

2 A sprinkle.

3 Erased and altered into xv.

4 Erased and 'laton' superscribed.

5 This entry erased.
} 


\section{INVENTORIES OF ST. MARGARET PATTENS, LONDON.}

Itm a vestement of rede cloth of Baudekyn with a dekon the Orphrayes blak saten with bellys of gold.

Itm a vestement of borde alisaundre with dekon and subdekon

Itm ij Copys of cloth of Bawdekyn the grounde rede

Itm a Cope of cloth of gold the grounde grene

Itm a Cope of cloth of Bawdekyn the grounde blak $w^{t}$ werkys of grene

Itm a Cope of cloth of gold chekered.

Itm a Cope of raye silk for a Childe

Itm ij Copes of rede silk for Children

Itm iiij awbys with the parelles of rede silk for Children

Itm ij awbys for Children with the parellys whyt

Itm a sengle vestement of rede veluet

Itm a sengle vestiment of cloth of Bawdekyn with the armys of the lord ffanope ${ }^{1}$

Itm a sengle vestiment of whyte silk

Itm a sengle vestement of rede silk with the Orfreys of blew silk

Itm a sengle vestement of demysay grene with purpitf \& whyte roses [in] the Orphrey

Itm a sengle vestiment of borde alisaundre $w^{t}$ the armys of Sir John Poph $\mathrm{m}$

Itm a sengle vestment of rede worsted the Orphreys of blak worstede the yeft of William harman

Itm a sengeff vestement of whyte borde alisaundre the Orphreys of rede veluet of the yeft of Sir Water Muschamp $p$ 'son of the said Chirche

Itm a sengle vestement of blak worsted with a dekon for Mortuaryes

Itm a sengle vestement of silke the grouncle rede $\mathrm{w}^{\mathrm{t}}$ the Orphreys of rede silk and whyte roses belongyng to our lady Chapett

Itm a sengle vestement belongyng to our lady Chapett of whyte silk $\mathrm{w}^{t}$ pe Orphreys blue silk $\mathrm{w}^{\mathrm{t}}$ Crownys of gold

Itm a sengle vestment belongyng to our lady Chapeff of Cloth of Bawdekyn the grounde of rede the Orphrys lyons and Pecokkys of gold

[f. 5 a.] Itm a sengle vestiment belongyng to our lady Chapett of grene silk with the Orphrayes of rede silk with bees of gold

Itm a sengle vestiment belongyng to our lady Chapefl of blew bokeram with whyte roses

Itm a sengle vestemient belongyng to our lady Chapeff of whyte ffustyan with Orphrayes of gold

(Added in another hand)

Itm a cloth of gold that s' wault' muschamp gave to the chirch

Awter. Itm for the high awter a ffronte and a nether ffront ${ }^{2}$ for the Clothes for high awter of rele silk with Swannys of gold and ij the high Curteyns of rede silk

auter. Itm for the same awter a ffronte and a nether ffronte steyned of the yeft of maister Thomas Wybbery Squyer

${ }^{1}$ Sir John Cornwall, K.G., created Lord Fanhope, 1433, and died 1444. His arms were, Ermine, a lion rampant Gules. crowned Or, within a bordure Sable beza nte .
2 In all these items "front" means the upper front, or dorsal : "nether front" means what we call the frontal. 
Itm for the same awter a ffronte \& a nether ffronte stejned $w^{t} v$ Joyes of our lady 1

Itm for the same awter a ffronte and a nether ffronte steyned of the lyf of Seint Margarete.

Itm for the same high auter steyned . a ffronte and a nether ffronte steyned like cloth of gold.1

Itm for the same awter a ffronte and a nether ffronte. of whyte for lent.

(Added in another hand)

Itm an awtr cloth of blake saresenett $w^{t}$ a crucifixe and mary $\&$ John $w^{t}$ curteyns for $\mathrm{y}^{\theta}$ same

Itm a blew say for the nether parte of $\mathrm{y}^{\mathbf{e}}$ awtr

Itm a fronte and a nep fronte steyned $\mathrm{y}^{\mathrm{e}}$ ovyr pte $\mathrm{w}^{\mathrm{t}}$ the resurreccon . the fad ${ }^{\mathrm{r}}$ son \& holy gost the asseyncon $\mathrm{w}^{\mathrm{t}}$ saynt Margett \& saynt Kat'yn | and $y^{e}$ ned ${ }^{r}$ pte is the nativitie of $o^{r}$ lord $y^{e}$ Circuficon (sic) and the epiphie

Itm ij supaltare on of $\mathrm{m}^{\prime} \mathrm{ble}^{2} \mid$ an op ${ }^{\mathrm{r}}$ of alabastyr'.

Awter Itm for the awter called our lady awter a ffronte and a nether clothes. ffronte steyned $w^{t}$ an ymage of $o^{r}$ lady and $w^{t}$ ij Curteyns for our lady of rede silke.

awt' Itm for the same awter a ffronte \& a nether ffronte steynerl $w^{t}$ ij Curteyns of the same sute

Itm for the same awter a ffronte and a nether ffronte steyned and $\mathrm{w}^{\mathrm{t}}$ Curteyns of whyte sillk new of the jeft of my lady atherley.

Itm for the same awter a ffronte and a nether ffronte whyte for lent. $w^{t}$ ij curteyns

\section{(Added in another hand)}

It' of $y^{\theta}$ gyft of rechard bowett a steneyth cloth $w^{t}$ his $m^{\prime} k^{3}$ $\& \mathrm{w}^{\mathrm{t}} \mathrm{y}^{\mathrm{e}}$ armys of $\mathrm{y}^{\mathrm{e}}$ stapytt of Calyc $\mathrm{w}^{\mathrm{t}}$ an ymage of hymself $\&$ a nodr of his wyffe $w^{t}$ a nether front $\& w^{t} o v^{\prime}$ front.

[f. 5 b.]

Awter Itm for Seint Johns awter a ffronte [and] a nether ffronte of

Clothes for Cloth of Bawdekyn with birdys of gold and ij Curteyns of Seint Johns grene silk.

awter. Itm for the same awter a ffronte and a nether ffronte of the lyf of Seint John steyned. $w^{t}$ ij Curteyns.

Itm a ffronte \& a countre ffront of whyte $w^{t}$ rede crosses for lent

Awter Itm for Seint marymawdeleyns awter a ffront and a nether

Clothes for ffronte steyned $w^{t}$ damask werk and ij Curteyns of the Seint Mary same

Mawdeleyns Itm for the same awter a nother ffronte and a nether ffronte awt' steyned $w^{t}$ damask werk and ij Curteyns of the same

Itm for the same awter a ffronte. and a nether ffronte steyned ${ }^{4} w^{t}$ ij Curteyns for lent of white, $w^{t}$ rede crosses.

1 This entry exased.

a i.e., marble.

VOL. IXXII
${ }^{3} \mathrm{His}$ ' mark' as a merchant

4 This word erased. 
Corpases $w^{t}$ Itm a Corpax $w^{t}$ a Case of cloth of gold the tone side rede Corpax and the other side blew

Cases. Itm a Corporax $w^{t}$ a Case of blew damask $w^{t}$ a fflowr de luce of gold

Itm $j$ Corporax $w^{t}$ a Case of blak veluet

Itm a Corporax with a Case of blak veluet old

Itm a Corporax $w^{t}$ a Case that one side thereof silk and that other silk with worke of gold

Itm a Corporax with a Case of grene silk $w^{t}$ a fflowr de luce

Itm a Corporax with a Case of grene silk

Itm a Case for a Corporax of rede damask fugory ${ }^{1}$

Itm a Case for a Corporax of grene damask

Itm a Case for a Corporax of silk $\mathrm{w}^{\mathrm{t}}$ a Crosse of silk

(Added in another hand)

A case of blew damaske $w^{t}$ a byrd of gold | the op ${ }^{r}$ syde of nedle warke $w^{t}$ Jhus \& a corpax p'in.

Itm a Corpax $w^{t} p^{e}$ case of blew tysswe $p^{e}$ on syde $\mid$ the $o p^{r}$ syde of rede cloth of tysswe

Itm a corpax $w^{t}$ the case $p^{e}$ on syde tawney saten $\mid$ the op $p^{r}$ syde of rede $w^{t}$ a flowr' of damaske

Itm a corpax $w^{t}$ a case $p^{e}$ on syde rede veluett $\mid p^{e}$ op $p^{r}$ syde gren sarsenett flowred $\mathrm{w}^{\mathrm{t}}$ brodered warke

Itm a corpax $w^{t}$ a case of Gren bawdekyn of $p^{e}$ on syde \& white on $\mathrm{y}^{\mathrm{e}}$ op ${ }^{\mathrm{r}}$ syde

Itm an op lyke to $\mathrm{y}^{\mathbf{e}}$ same

Itm a Corpax case of rede veluett on veluett $\mathrm{w}^{t}$ gren trulove flowres and a cloth of dyap for the pyxte p'in.

ffrontels Itm a ffrontelf of cloth of gold $w^{t}$ a Cloth therto

and lynen Itm a nother of rede silk $\mathrm{w}^{\mathrm{t}}$ sterrys of gold $\mathrm{w}^{\mathrm{t}}$ a cloth therto

Auter Itm a nother fronteft of whyte damask

Clothes. Itm a nother ffronteff of sille with werkys

Itm a nother ffrontetf of Tawny veluett with whyte roses

Itm a nother ffrontelf of Cadas ${ }^{3} w^{t}$ birdys

Itm a ffrontełf of blew silk enbrowded $w^{t}$ fflowres without a Cloth

Itm v auter Clothes of dyaper

Itm iij auter clothes playn ${ }^{4}$

Itm ij howselyng towellys of diap

Itm iij smale towellys iij Dyap and $j$ playne for preestes to wype on peir hondes.

(Added in same hand)

Itm iiij lynen Clothes for frontels

(Added in another hand)

Itm ij awlter' clothes of Dyapr \& a toweft of the gyft of $\mathbf{S}^{\prime}$ John Donton

(Added in a different hand)

(In another hand.)

The xxv day of Juyn $a^{\circ}$ lxxvj...ij awter clothes \& towell labbrd

It' a awt' cloth of $y^{e}$ gyft of aveys hatt $w^{t}$ ilic in $y^{e}$ medytt.

${ }^{1}$ i.e., figure.

${ }^{2}$ Frontal means the narrow strip sewn as an apparel to the linen altar cloth, now called_superfrontal.
3 Cadas, or carduus, an inferior silken stuff.

This line erased These are the linen altar cloths. 
INVENTORIES OF ST. MARGARET PATTENS, LONDON. 319

Clothes for Itm $\mathrm{j}$ Cloth to hang afore $\mathrm{y}^{\mathrm{e}}$ rodeloft steyned of the lyf of Ymages Seint margarete

Itm an other Cloth for the same rode loft of the passion of our lord

Itm $\mathrm{j}$ Cloth to hang afore the rode in lent

Itm $\mathrm{j}$ Cloth steyned to hang afore Seint margarete.

Itm a nother Cloth to hang afore our lady

Itm a cloth to hang afore Seint Kateryn steyned

Itm a new cloth steyned for the lectorn

Itm $\mathbf{j}$ old Cloth for the lectorn steyned

Itm $\mathrm{j}$ Cloth of whyte \& blew called a vaytl for lent

Itm $j$ cloth of rede worstede to lay afore the awter in high ffeste

Itm $\mathrm{v}$ clothes steyned to hang afore the ymages of the Churche in lent

[f. 6 a.] Itm a crosse Gylt $w^{t}$ a staffe of Silv' werke

Itm a miter for Seynt Nicholas off white damaske embrodred with bellis of gold

Itm a Grete cloth of Tapestri werke for to hang uppon the Walle by hynde the Sepulcur

Itm a steyned Cloth of Sepulcur werke $w^{t}$ the Ressurreccion. the Passyon . and $\mathrm{w}^{\mathrm{t}}$ other werkis

It' ij crosse staves paynted $w^{t}$ silv'

Itm a blake cloth for mortuaryes

Itm a Canpye of grene cloth of Bawdekyn frendged $w^{t}$ silke.

Baners. Itm a Banner of red sillke beton $\mathrm{w}^{t}$ lyons of Silver.

Itm a baner of silke beten $\mathrm{w}^{\mathrm{t}}$ the armes of Maist' Atherley

It' anoder banner of blewe bokeram beten $\mathrm{w}^{t}$ gold.

Itm a stremer of blewe bokeram betyn with gold

Itm a nother Stremer of silv' betyn $w^{t}$ Davy Trebleffelde armes.

Itm iiij banners on steyned of Seint George Anodr steyned $\mathrm{w}^{t}$ a vernacle Another steyned $\mathrm{w}^{t}$ the holy goste

Itm a nother Steyned $w^{t}$ the ymage of our lady

It' $i j$ white banners steyned $w^{t}$ the passyon of our lord

Itm ij crosse banners of grene silke that on of theym beten $\mathrm{w}^{\mathrm{t}}$ the resurreccion And the top' of theym beten $\mathrm{w}^{\mathrm{t}}$ the ymage of Seynt Margarett

Itm a crosse cloth steyned $w^{t}$ the resurreccion

Itm iij smale pynons of silke $w^{t}$ the armes of Maist' Atherley

(Added in another hand)

Itm a new Crosse cloth of $y^{e}$ assupcon of $o^{r}$ lady $w^{t}$ saynt margett \& saynt Kat'yn and $w^{t} y^{e}$ v. woundes of $o^{r}$ lord the ground y'of is gren sarsenett. and ij smale belles on $y^{\theta}$ staffe.

Surpleis Itm iij newe Surpleis

Itm a rotchett for a child

Itm a Chiste bounden $w^{t}$ Iron In the Vestri

Itm a nodr Chiste in the same Vestiary bownden $w^{t}$ Iron

Itm ij Kuyshons of diapir werk

Itm a Canapye cloth steyned for corp 9 xpi day

Itm ij sakeryng belles 
Itm ij Surpleices

Itm iij smale bellis for the Canape

Itm a rotchett of the gyft of Thirlkyld

(Added in another hand.)

Itm iiij. new Surples bowght be John Jeffray \& Wiffn Bothom Churchewardens in $y^{e}$ yere of Sov'ayn lord the kyng henry the vijth the xxijti the $\mathrm{p}^{1} \mathrm{c}^{\prime} \ldots . . . \mathrm{xxj}$ iiijd.

Itm vij. smale beftes and a lynen $w^{t}$ a Redile crosse to hynge up on the dedycacon day

Kerchefes Itm a kerchieff of lawne $w^{t}$ taselx of white silke And iij knoppes of silv' \& silke

Itm a nodr kerchief of uinple $w^{t}$ iij knoppis sett $w^{\mathbf{t}}$ peritt ${ }^{\mathbf{l}}$

Itm ij other kercheffes of lawne $w^{t}$ iij taselx either of theyn.

(In another hand)

Itm a valans of Blacke bokeram frynged $w^{t}$ Cruełf wryton $\mathrm{w}^{\mathrm{t}}$ greate l'res of Gold I desyr reste / of $\mathrm{y}^{\mathrm{e}}$ gyfte of $\tilde{\mathrm{m}}$ angell don' (Donne or Dunne) and xxiiijts smalf pendentez

[f. 6 b.]

Here Aftyr ffolowyng been the Ormamentes. And gyftys. that was Gotten And gyvene to the use propyrlye. of Seynt Margarete Patten Churche. Standyng In the towre strete end In london. The wiche is gotten and. labored to be hadd. for the same Chirche use. by maist' Tho mas howghton . than beyng parsson of the same Chirch And by maist' Robt Bangylt . and by maist' John Thrilkyld Grocers of london of the same parysshe. In their tyme off their Wardeynshipp . off the same Chirch That is is [sic] to Witte . from the fyrst day off marche. In the yere of our lord god . xiiijclxxix ${ }^{\circ}$ unto the vij day off Marche In the yere of our lord god . xiiijclxxxvj , att their gevyng upp off their Accowmpt.

In $\mathrm{p}^{1} \mathrm{~m}^{9}$ we labored to have $A$ vestyment . the hole sute of red tyssewe that is to witte preest. Decon. and la $^{\mathrm{a}}$. marc'. subdecone. $w^{t}$ a cope. for the wiche we paid ffore $\mathrm{Sm}^{\mathrm{a}}$

Itm A White Cope of Damasske powderd with Archangelles and the Offeraries of the same of nedyll werke of a parte of the lyffe of Seynt Margarett. to the whiche payment of the same Cope. We had of the bequest of Richard Bowell and Elyzabeth his wyff by the handz of Sir John Plomer preest and Executor to pe $\quad S m^{2}$ - viij fi st and we paid the ov'plus $\mathrm{ix}^{\mathrm{li}}$

Itm ij White Copes of white Damaske powderd $\mathrm{w}^{\mathrm{t}}$ fllowres of silke and gold And the Offeraries of red-velowett the which we had geven to the Chirche ffor ix $^{1 i}$ xiij $^{\mathrm{s}}$ iij $^{1}$ the sowle off Sir John Thoode preest by the handz of )
our forsaid parsone price of theym

Itm A Sỹgyll Vestement had for the soule of sir John thoode preest of redboordalisannd ${ }^{x} w^{t}$ rosez of gold In the crosse of the same on the bakke p'of is $\left(\mathrm{red}^{2}\right)$ ? grenebordealisaund ${ }^{\mathrm{r}} \cdot \mathrm{p}^{\mathrm{l}} \mathrm{ce}$

1 These are pyx cloths.

2 Erased. 
Itm A nother Syngill. Vestement had for the same sowle by the handz of our said parson of red silke $\mathrm{w}^{\mathrm{t}}$ ) white roses and the crosse on the bake perof is white silv'e And is name written In the middes of the same / crosse $\mathrm{p}^{\mathrm{i}} \mathrm{ce}$

Itm A vestement of white Bokeram. for to serve for lenton had by the handes of our said parson $w^{t}$ red ? spottes and a redcrosse on the bake and Jtis writt' in ? the myddes of the same crosse price of the Same ! vestymet

[f. 7 a.]

Itm a Vestyment $\mathrm{w}^{\mathrm{t}}$ greenbordealisawnder $\mathrm{w}^{\mathrm{t}}$ a redcrosse) and White Spottes of silv' and roses of gold the I which we had for the Soule of maistr Drope aldreman? price

Itm A Vestyment of the bequest of mast' John Darbye Aldreman of white cheker Coloure red and grene with a rede crosse on the bak and his name In the myddes $p^{r}$ of

Itm we have of the bequeste of the forsaid Richard, Bowett and Elysabeth his wyff by the handz of the forsaid Sir John Plomer executour to the same. A $>$ Crosse silv' and gylt $\mathrm{w}^{t}$ mari' and Johne weying by , troy Weight . lxxxvij ownces \& iij quarterns

Itm of the Gyfte of Annes Wym'ke a paxbred silv' $\&$ gilt weying vj ownces di . $w^{t}$ blewe rosez and $w^{t}$ ? the salutacion of our lady . the wich paxbred is geven ? for the soule of Sir Thomas Avelen preest price

Itm of the gyfte of Annes wymarke ij kuysshons of. tawney chekr werke $\mathrm{w}^{\mathrm{t}}$ tassellz of blew threde price vjs viijd It' a Coverlett of the gyft of the same Annes Wym'ke of grene tapest' werke of flowrez . to ley ou' ! the grownd to fore the high awt'er. vij

Itm by the handes of our said mast' parson ijj kuysshons $+{ }^{1} \mathrm{w}^{\mathrm{t}}$ iij pellicanez on theym of tapest' werke $\mathrm{p}^{\mathrm{I}} \mathrm{ce}$ vijs It'

+ of the same mast' parson $j$ bankur of tapest' werke $w^{t}$

+ ffloures price iijjs It' by our said parson a White -Coverlett of tapest' werke $w^{t}$ yelow fflours and grene lyned with canvas $\mathrm{p}^{\mathbf{i}}$ ce ixs $\mathrm{Sm}^{\mathrm{a}}$ tof

Itm ij newe awter Clothes ffor lenton of our said $\tilde{m}$ ' parson on above the awter $w^{t}$ the cruciffixe of our lord and a nod ${ }^{x}$ be neyth the awter $w^{t}$ the Sepulcur of our
lord $\mathrm{Sm}^{\mathrm{a}}$

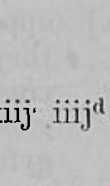


Itm A crosse staffe graven and gylt like goldsmyth werke $\mathrm{w}^{\mathrm{c}}$ the crown of Seint Margarette by the same Mast' parsson price

Itm the rode aboven the Roodlofte In our Chirch with? mari and John the same Crosse newe made and newe $\succ$ xxxiij ${ }^{\circledR}$ iij $^{d}$ paynted and gilted by the cost of the said ñi parson J

It A Crosse staffe like white silv' newe paynted of the ? coste of Richard Kyrkby payntor

Itm iij Stavys paynted ffor the Canapye wt corp 9 x'pi) uppon theym And $w^{t}$ iij angellz gilt to stand uppon theym by our said maistr parson price $\mathrm{xx}^{\mathrm{B}}$ Itm a! crosse and a Crosse staffe to serve for lentton payntid i green withoute ymages $\mathrm{w}^{\mathrm{t}}$ iij white silv' nailis by the gyft of our said mast' parson price iij iij $^{\mathrm{d}} \mathbf{S m}^{\mathbf{a}}$

Itm the ffownte in our Chirch newe ledid and newe gilt ! and $w^{t}$ all $p^{t}$ langes $p^{\prime}$ to by $m$ parson

Itm a nod ${ }^{\mathbf{r}}$ crosse for the Sepulcur havyng relikes therin ? by our said in parson

Itm an awter cloth oin aboven the awter and a nother beneyth white steyned $\mathrm{w}^{\mathrm{t}}$ gold braunches $\mathrm{w}^{\mathrm{t}} \mathrm{a}$ ) rynnyng vyne thorowe $w^{t}$ a Crucifixe above and $w^{t}$ \} Seynt John the Baptist beneith by our said Mast')
parson price

Itm a frontel of white damaske doble $\mathrm{w}^{\mathrm{t}}$ rosis of gold and ymages of Seint margarett made In nedill werke $\mathrm{Sm}^{\mathrm{a}} \mathrm{xxj}^{\mathrm{B}}$ It' a ffoote for our best crosse gilt by mast' $x \times \dddot{x i j}^{\mathrm{s}}$ viija parson $x^{d}$

Itm a nother fote for the Silver crosse made by the coste $)$ of Richard Kyrkby payntor

Itm a boke callid an ymner notid thorow. and an olde) manewell and ij beriall bokes on of theym noted $\mathrm{w}^{\mathrm{t}}$ ? drige price of theym had by mast' parsone

Itm a braunche the wich standes to fore Seynt Margarett ? of the Gyfte of Elsabeth wym'ke

Itm we labered to be had in the same tyme . viij Corporaxis casis with Corporaxis p'in on of theym blew tissewe Itm a noder of theym white damaske wt ij archangellz It' a nother redvelowette with a fllourdeluysse ${ }^{1}$ It' the $\mathbf{v}^{\text {th }} \mathrm{w}^{\mathrm{t}}$ the grounde red and a white flour of Silv' bordered rounde aboute $w^{\mathrm{t}}$ yelaw and blewe It' the vjth $\mathrm{w}^{\mathrm{t}}$ redsilk and byrdes of white silke It the vijth $w^{t}$ blake slke and redrosez It' the viij with the ground redsilke And a redcrosse of gold In the myddes $\mathrm{w}^{\mathrm{t}}$ oylett holis of silv' had 'by mast' pson price of the same $\mathrm{xxvj}^{\mathrm{s}}$ viijd. Sm $\mathrm{So}^{\mathrm{a}}$ of theym

1 The fourth is not given. 
Itm an awter Clothe of diapir of the gyfte of Annes Wym'ke the werke therof is fllourdelusis and crownez $\mathrm{w}^{\mathrm{t}} \mathrm{v}$ redcrossis theron and Jhis in $\mathrm{p}^{\mathrm{e}}$ middes It' a noder diapir Cloth off fyne diapir had for the soule of Sir John Dowton $w^{t} i j$ crossis in the myddes and Jhis $+h^{\mathrm{c}}$ In the myddes of theym $\mathrm{w}^{\mathrm{t}}$ a crowne of grene sylke + defic $^{t}$ Itm a nod ${ }^{r}$ awter cloth crossdiamowndes $w^{t} \quad v$ crossis In hitt of the gyft of mast' Thirlkild and his wyff It an nodr awter cloth of diaper $w^{t}$ Jhc crowned in the myddes $w^{t}$ a lett'. a. undrneith of the gift of annes hatf It' an nod $^{\mathrm{r}}$ awter cloth of byrdes eyon werke $\mathrm{w}^{\mathrm{t}}$ a crosse In the myddes and writt' und'neith of the gyft of Bowenpersons wyff baskettmaker Itm a grene silk cloth for to serve for the pulpitt and to ley uppon dedcorsis of the parish $w^{t}$ serpentes p'in of mastres bangillz gyft

Itm iiij newe paxbredes ij of the Resurreccion of our lord and the top' ij of Seynt Margarett.

Itm ij lectron Clothes steyned of the gyft of mast'? parson price of theym

Itm the cloth for the rood In lenton steyned by the said ? maist' parson price.

$\left[\begin{array}{lll}\hat{k} & 8 & \text { a. }\end{array}\right]$

Itm xvj bolles of latton langyng ffor the rood lofte small 1 and grete $\mathrm{p}^{\mathrm{e}}$ which cost

Itm a Tabernacle $\mathrm{w}^{\mathrm{t}}$ the Creuite and wt a hovell aboue ) hitt In the quere on the Sowth sicle at the high awter had by the same Maist' pson p'ce

Itm had off my lady Edward iiij banners ffor the tyme of Est' of silke and betyn $\mathrm{w}^{\mathrm{t}}$ gold and silver $\mathrm{w}^{\mathrm{t}}$ mast' Edwardes armes In theym and the armez of london

Itm We had of the bequest of the forsaid Richard Bowell . and of Elysabeth his wyff the which she her self by her ! lyff delyv'd unto our for said mast' pson ffor to pay > for sylyng of the yle. and the South side of our Chirch ) thorow

And our said Maist' parsson pd more paid more on his ? purs above that

With many other necessaries done, and Ocupied to the behoofe of the forsaid Chirch Seynt Margarett Patten the which he will natt have rehersid nor knowen

Itm a Vestement off greenebordealisawnd ${ }^{x} \mathrm{w}^{\mathrm{t}}$ a crosse In ) the bakke theron off blewe chekyrwerke off the gyfte of Mast' John Thrilkyld and his wyff. price

(Added in a different hand)

Item a Cope of Whyte damaske fflowryd $w^{t}$ fflowre de lyce brodyrd $w^{t}$ gold off $\mid \mathrm{ve}^{\mathrm{n}} \mathrm{yse}^{\mathrm{l}}$ off $\mathrm{p}^{\mathrm{e}}$ gyfte off mastr harry Wayte m'c' \& merchand off $p^{\mathrm{e}}$ stapull and dekyn \& subdekyn longynge to ye same.

$v^{s}$

iijs $^{\mathrm{siij}}{ }^{\mathrm{d}}$

$x v j^{3}$

$\mathrm{xx}^{\mathrm{s}}$

$\mathrm{xl}^{\mathrm{B}}$

$\operatorname{Sm}^{n} x^{1 i}$

$v$ viij $^{\mathrm{a}}$

\footnotetext{
1 Gold of Venice,
} 
It' we have all so ij masers on by $p^{e}$ gyfte of my lady adyrley and anop $\mathrm{By} \mathrm{p}^{\mathrm{e}}$ gyfte off Wyllyam 1orneton hyr s'vand

It' a dyapur clope ffor $p^{\theta}$ hye Awter off $p^{\theta}$ gyfte off I modyr staynysmore owre tenant The lengpe $p^{r}$ off $\}$ iiij yardes

It' a Covyr ffor pe sakyrment | or ftor pe best Crosse off ? changeabuft sylke by pe gyfte off Richard pownd

It $\mathrm{xl}^{\mathrm{s}}$ off money By $\mathrm{p}^{\mathrm{e}}$ beqwest off Wyllyam Johnson basketmaker Apon Hose sowle Jhc have mercy gyvyn | $p^{\theta} x^{\text {th }}$ yere off $p^{e}$ regne off Kynge harry The viith That tyme beynge Wardens off $p^{\theta}$ seyd seynt marget paresche John Wryght \& John Jeffrey

It a masse bocke by $p^{e}$ gyfte. of mast ${ }^{p}$ adyrley lymyd ) w gold

[f. 8 b.]

(In another hand)

Itm an Autter Cloth at the gyffit of the wyffe of Ric' pound of dyapp to the honor of god \& Seynt margitt the yer' of $o^{x}$ Sovereyn lorde Kyng henry the viith
xiiijth

Itm by the bequeste be of margit wyolett wyddow to the) hono ${ }^{\mathrm{r}}$ of god \& Seynt margit a torche on whos Sovle Jeћu have m'cy

Itm we have a Canstyk of latten at the gyfte of margit harppha ${ }^{a}$ the yerre \& tyme afforseid

Itm a torche at the bequeste of mastres pynde to the honor of god \& Seynt margit on whos Sowfl Jtiu have m'cy

Itm we have an avtter Clothe of dyapp to the Avtter Affore mastres Stavntton, ${ }^{7}$ the wychemastres Stavntton gaf it to the honor of god and seynt margaret the $\left.x v^{\text {th }}\right\}$ yerre of Kyng $\hbar$ the vijth

Itm we have iiij torches at the gyft of mastres bretten $\mathrm{ffo}^{\mathrm{r}}$ the Sovle of mavde her dowghter the whiche

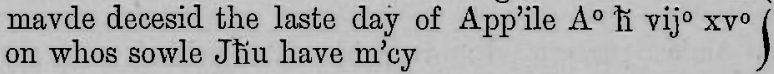

Itm we have a Savtter of olde hand written Cyv'id wt whit leddyr the Saltter Sy ${ }^{r}$ John Skeltton gave it to ! the honor of godd \& Seynt margit the yerre and tyme to ffore seid that tyme beyng Chyrche warddens Jotin | Smyth \& hywg madderson of $p^{e}$ same Chyrch

(In another hand.)

Itm A Suete of Blake veluett. $\mathrm{pt}^{\mathrm{t}}$. is to wytt . vestment . . Decon . and subdeacon. $\mathrm{w}^{\mathrm{t}}$ a Cope of the same $\mathrm{w}^{\mathrm{t}}$ ) orfrays of nedle warke wt the appostolles \& pphetes of ? the Gyfte of Robt may John Wylson and Jotin ${ }^{2} p^{r}$ ! wyffe on whos ssowles J'hu have M'cy. the $p^{i} \mathrm{c}^{\prime}$

${ }^{1}$ There must be some error here. 
Itm $\mathrm{j}$ Suet of whyte damaske wt Orfrays of Redde veluett. wt flowres of nedle warke $\mathrm{pt}^{\mathrm{t}}$ is to wytt. vestment. deacon . \& Subdeacon . of the Gyfte of mastr henry wayte

Itm a Cote for Sent margarett of white damaske. werged wt blake veluett \& lyned with gren bokeran . $w^{t}$ an owch of Sylv' Gylt \& ennameled \& a ston cowched in sylv'

Itm a Cote for our lady of white damaske braunched $w^{t}$ Roses | an op ${ }^{r}$ of cloth of Gold

Itm a paff of veluett Rowed white. Redd . and blew

Itm a cloth of white sylke for $p^{c}$ Canopye $w^{t}$ taselles of Redde sylke

Itm ij clothes of Redd sylke for $p^{e}$ pyxte on $w t$ balles of gold

[f. 9 a. $]$

Itm ij Sudarys of Redd sybt ${ }^{1}$ po on ys frynged $w^{t}$ blake

Itm ij . lytyll botels of Glasse $w^{t}$ Jhc xpe wryton on pem

Itm iiij tacelles of Sylke sette $w^{\mathrm{t}}$ perle \& pyseled Gold

Itm iiij tacelles of Reddle sylke for the Canape $\}$ for pe canope

Itm a thyng to ber' holy candle in $\mid$ on Candlemasse day for pe p'ste

Itm a prykett Candell stycke

(In another hand, the same that made the first additions to this list)

It' we have a shyppe ffor to put yn ffranke ensens off sylv' psell gylt $\mathrm{w}^{\mathrm{t}}$ a spone off sylv' $\mathrm{p}^{\prime} \mathrm{yn}$ by pe gyfte off John Wylison \& robard maye \& jone $p^{r}$ wyffe $p^{c} \mathrm{xx}$ yere off $p^{\mathrm{e}}$ regne off Kynge herry $p^{\theta}$ vijth Chyrche Wardens $\mathrm{pt}^{\mathrm{t}}$ tyme beynge John Jefferey and Wyllim bothom

It' we-have a awt' clope off pe gyfte off Jone maye \& a towell off dyap

[f. 9 b. Blank.]

(On another page, but in the same hand as the inventory) [f. $10 \mathrm{a}$ ].

Itm a mytor for seynt Nycholas of white sylte $w^{t}$ sterrys \& p'cyouse stones $^{2}$

Itm a Crosse staffe Gylte wt a napkyn p'for.

[ff. $10 \mathrm{~b}, 11,12,13,14,15$. Blank.]

[f. 16 a.]

This is the Inventory of all the goodes Juelx and Ornamentis belongyng unto the Chirche of Seint Margaret Pateyns in London made the xxiij ${ }^{\text {th }}$ [sic] day of the Moneth of January The yere of oure Lorde god $\mathrm{MI}^{1}$. va XI And in the $\mathrm{Vij}^{\mathrm{d}_{\mathrm{e}}}$ yere of the reigne of Kyng Henry the viijth that tyme beyng pson Maister Rowland Philipp And wardeyns of the same Joln Sampson Salter and John Momforde . otherwise called John Smythe Plaisterer Citezeris . of London

'Sic, for "sylke."

2 This entry is erased.

VOL, XLII 


\section{INVENTORIES OF ST. MARGARET PATTENS, LONDON.}

(The following entry and the weights appended to the items below, are interpolated in a different hand)

$\mathrm{M}^{\mathrm{d}}$ Here folowith a new content of weight of all the pcelles underwretyn truely the $6^{\text {th }}$ day of Aprell 1526 . in the p'sens of $p$ 'son John Champneys John Sampson John Smyth John Geffrey Richard brown John Cary Robert Millis Henry Clerk \& George Spragyn

Juelx ffirst a Crosse of silv'e and gilt with a Crucifix and mary and John in the same of the gifte of Richard Boweff and Elizabeth his wiff weying lxxxvij unces iij qrterons

lxxxxix onz $q^{a} r$

Itm a Crosse of sylver $w^{t}$ a Crucifixe in the same peell gylte weying lv unces di 1 lviij onz $q^{\text {atr }}$ đैi

Itm the best chaleys of Sylver and gylte $\mathrm{w}^{\mathrm{t}}$ a crucifixe and mary and John enameled in the same And in the fote of it iij half mones. otherwise called Knappes. And in the pateyn of the same the holy lambe. enameled wt a Chaleys graven under the same ${ }^{1}$ weying $x$ viij unces

xviij onz \& $q^{\mathrm{a}} \mathrm{r}$ đ

Itm a Chalyce of sylver and gilte and a hande graved in the pateyn of the same weying xij unces iij $q^{\mathrm{a}}$ terons di

xij onz

Itm a Chaleys of sylver and peeff gylt and a Patene wretyn in the fote of the gifte of the Brethern of Seynt Margaret Patentes weying xxv unces di $q^{\text {artez }}$

xxv onz đi $q^{2} \mathbf{r}$

Golde $^{2}$ Itm a Chaleys of sylver and peeft gilt and a small vernakytt gravyn in the Patene of the same weying xiiij unces $j$ qant' di

${ }^{3} \mathrm{~A}$ Chalis $\mathrm{M}^{\mathrm{d}}$ this Chalis was solde 4 yers past by the assent of the pissh and a nother Chalis broken wt a patent weied now . $\&$ dd to henry Clerk for to amend poiz $\mid x j$ onz iij $q^{\mathrm{R}} \mathrm{T}$ di

Itm a Monstez with a fote of sylver and gylte of the gifte of Sir John Dunton preist weying lvj unces $j q^{u} t^{\prime}$

lb jonz qar

Itn a Pixe of sylver pcell gylte and the Trynite gylted in the toppe of the same $\mathrm{w}^{\mathrm{t}}$ saynt Margaret in the fote of the same weying xxviij unces iij $q^{\mathrm{n}} \mathrm{t}^{\mathrm{t}}$ đa $\quad$ xxix ońz $\mathrm{q}^{\mathrm{a} r}$

[f. 16 b.]

Item a paire of Candelstyckes of Sylver and pcell gylte weyin: xxxiiij unces xxxij onz iij q ${ }^{\mathrm{a}} \mathrm{r}$

Itm twoo Basons of Sylver and pceff gylte with Rooses in the myddes of the same weying xxiiij unces i $q^{\mathrm{a}}$ rteron xxiiij oñz $q^{a} r$

Itm twoo Sensours of Sylver pceff gilte weying liiij unces lxxxij onz iii $q^{a} r$

1 A very unusual device.

2 Interpolated when the plate was re- weighed.

3 The whole of this entry is interpolated. 
Itm a Shippe of sylver pceff gilte $w^{t}$ a lambe gilte and a spone concernyng to the same of the gifte of Robert Maye John Wylson and Johain their wiff weying xv unces $j q^{a^{2}} t^{\prime}$ $x v$ onz $q^{a} r$

Itm a paxe of Sylver and pcell gylte $w^{t}$ blew Rosez and $w^{t}$ the Salutacion of oure Lady in it of the gift of Agnes Wym'ke for the soule of Sir Thomas Avelen Preist weying vj unces di

vj onz di

$M^{\text {dl }}$ Itm a Crismatory of sylver peell gilt weying xiij unces. $j$ $q^{i} r^{\prime} t^{\prime}$

Itm a pixe of Ivery for the Sacrament of the alter to be putt yn and bounden aboute With sylver. weying iij unces iij qart' iiij onz iij $q^{a} r$

Itm a Relyke of sylver and ou' gylt sett $\mathrm{w}^{\mathrm{t}}$ stones [and a pece of the Holy Crosse $\left.{ }^{2}\right]$ in the same weying ij unces

$\mathrm{j}$ onz iij $q^{\mathrm{a}} \mathrm{r}$

Itm a Case of sylver and gylte and saynte Kateryn of sylver and gylt closed within the same weying iij $q^{\text {a rterons of } j}$ unce iij $q^{a} r$ of a onz

Itm an Oche of Sylver and gylt wt a garter enameled in the myddes of the same weying di unce di $q^{a} \mathrm{rt}^{2}$

di onz jd $q^{a} r$ weight

Itm twoo Masoures $\mathrm{w}^{t}$ bondes of sylver and gylte $\mathrm{w}^{\mathrm{t}}$ booses in the myddes of the same one of theym of the gifte of Maistres Thorneton with Ihuc in the same Boose and in the bonde of the same wretyn Domine salvu me fac weying ix unces di $q^{a} \mathrm{rt}^{r}$

And the other Masoure is $w^{t}$ a Boose gylted in $\mathrm{y}^{\imath}$ wtoute amell' and on the bonde on the oute syde of the same wretyn Of goddes hande blissed he be. That taketh this Cuppe and drynketh to me. And on the Inne side of the same bonde is wretyn. God that suteth in Trynyte. sende us peax'e and vnyte. Weying xij unc' j q $q^{\mathrm{a} r t}$ ' di

bothe together poiz $\mathrm{xxj}$ oñ $q^{\mathrm{a} r}$

\section{(Added, in the same hand as the inventory.)}

Itm a Rechester of sylver ${ }^{3}$.

${ }^{4}$ Itm a $p$ of Cruettes of Silver pcell gilt weying xij onz di

[f. 17 a.]

Copes. Itm a Cope of Redde Tyssew

Itm a Cope of white damaske $w^{t}$ arkeangelles the Orferas of the same of nedytt Warke with parte of the life of Saynt Margaret of the gifte of Richard Bowett and Elizabeth his wiff

ltm twoo white Copes of white damaske powdered with fflowres of sylke and gold and the Orferas of the same Redde veluett of the gifte of Sir John Thoode Preist

1 Added.

3 Was this a book marker?

2 These words erased. This line added when the plate was reweighed. 
Itm a Cope of White Bawdekyn $w^{t}$ Byrdes

Itm a Cope of grene Bawdekyn with branches and Birdes

Itm a nother Cope of grene and black Bawdekyn

Itm a Cope of black veluett the Orferas of the same of nedyli worke With the Apostelles and pphetys of the gifte of Robert Maye John Wylson and Johañ their Wiff

Itm a Cope of Reilde veluett the Orferas.

Itm twoo grene Copes of olde Bawdekyn

Itm an olde Cope of Cheker Workes

Itm iij Copes for Childerne

[f. 17 b.]

Vestymentes In pimis a Sute of Redde tyssewe for preist Deacon and Subdeacon the Orferas of the same grene tyssew

Itm a Sute for Preist Deacon and Subdeacon of White damaske the Orferas of the same of Redde veluett $\mathrm{w}^{\mathrm{t}}$ fllowres of nedyll warke of the gifte of Maister henry Wayte

${ }^{1}$ Itm a Suet of Black velvuett for preist Deacon and Subdeacon the Orferas of the same browdered with Imagez of the gifte of Robert Maye John Wylson and Johan their wiff 2

Itm a Suet of whyte Bawdekyn for Preist Deacon and Subdeacon the Orferas of the same redde sylke browdered with fllowres and grene leefes

Itm a Suett of Relde veluett olde for Preist Deacon and Subdeacon the Orferas of the same of nedylf worke

Itm a vestyment of Redde veluett the Orferas of the same blewe browdered with sterres

Itm a vestyment of White sylke the Orferas of the same blewe browdered with sterres

Itm a olde vestyment of White sylke the Orferas blewe browdered with Crownes

The next five folios are lost; but there is a loose one left which may be 23 .

[f. a.] Item a Banner cloth of olde sylk $w^{t}$ armes of hertes heddes

Itm twoo steyned Banners of Clothe of one of the vernacle and a nother of oure lady $\mathrm{w}^{\mathrm{t}}$ sonne beames in the same

Itm twoo Banner Clothes of the passhion steyned for lent

Itm a vayle for lent to hange before the high awter

Itm a Crosse cloth for lent to hange before the Roode

Itm a Clothe for lent to hange before the Srevyng pewe ${ }^{3}$

Itm viij olde clothez to cov'e sayntes $w^{t}$ all in lent

Itm iiij small Banners of lenyn .clothe paynted s'vyng to hang aboute the pascall at Ester

${ }^{1}$ Inserted in the margin "Here laks a "See note ante, as to whether the woman deken."

had two husbands liping.

3 The confessional. 
Stremers In $p^{i}$ mis iiij strem's of sylk of the gifte of $M$ Angeff Dunne and wherof one of the stapull armes of Calice a noder of the standerdes Grocers armes the iij de of the armes of london and the iiij ${ }^{\text {th }} \mathrm{w}^{\mathrm{t}}$ an unycorne made in sylv'e $\mathrm{w}^{\mathrm{t}}$ Crosses of gold in the same

Itm iij other strem's of sylk wherof one of theym is $w^{t}$ black Choughes a nother strem' of black sylk w $w^{t}$ fres of gold wretyn Knowe thy self a nother of the Grocers armes and the iijth of the armes of london [Itm $\mathrm{ij}$ of the stremers Be cloth $]^{1}$

Itm a strem'e of blewe Bokerham $w^{t}$ barres of gold and sylver in the same

Itm a standerd of sylk $w^{t}$ a Rampion lyon in the same

Itm a strem' of Canvas $w^{t}$ blewe trayfulles in it

Itm a standerd of sylk $w^{\mathrm{t}}$ iij splayed Egels of golde twoo black lyon heddes and iij Crosses of sylver in the same

[f. b.] Itm a Canapie s'vyng for Corpus xpi day to bere in the pcession ou' the Sacrament $w^{t}$ iij stavys and angelles concernyng to the same

Itm twoo Angelles for the Sepulcre.

Itm iiij Castelles s'vyng for iij torche staves on Corpus xp̄i day

Cotes Itm ij Cotes of clamaske for saynt Margaret one of theym of s'vyng for white damaske bordered with blew veluett

Seynte Itm a noder of black damaske borclered above $w^{t}$ Clothe of golde frenged beneth with sylk and a Shelde of the salters armes in it of the gyfte of John Sampson

Itm a longe Kerchietf of Sypers frenged $w^{t}$ sylk at bothe endes for seynt Margaret of the gifte of Johan Sampson

Itm twoo Cotes for oure lady one of tawny clothe of golde and a noder of white damaske browdered $w^{t}$ fflowres

Peawter Itm a peire of Candelstyckes of peauter

Itm iij payres of Crewettes of peauter

[f. 24 a.]

$\mathrm{M}^{\mathrm{d}}$ that the $\mathrm{xxviij}$ day of Jenefer the $\mathrm{x}$ yere of our soverayne lord kyng henry the eight restes in sterlyng money in the lytell howche lvjif where of $\mathrm{M}^{\mathrm{r}}$ John Smyth paynter hathe on key \& Mr John Jeffrey tyler hath a nother key

$\mathrm{M}^{\mathrm{d}}$ that maist ${ }^{\mathrm{r}}$ moinors and maist ${ }^{2}$ Sampsone hath recevyd for the churche parte a Image of silver licke a wooma $w^{t}$ chylde and a nother Image licke a getyft wooma and a plate of Selver $w^{t}$ the pycture of a getyft wooma . and a plate of Selver of the pycture of a hedde of a wouma and a harte of Selver gylte. aft the same weyth xij unces the whych ys aff dyue to sant margaretes churche Ite recevyd of havferey inomors the xij day of decemb $\mathrm{an}^{0} 1521$ | for the reste of my parte in fufte payment iiij" ster' Rowland Inkys. 
$\mathrm{M}^{\mathrm{d}}$ that the iiij clay of July $\mathrm{A}^{\circ}$ dni . 1536. $\mathrm{A}^{\mathrm{o}} \cdot 28 . \mathrm{H} .8$. in the p'sence of $\mathrm{m}^{\mathbf{r}}$ John Grene parson of seint Margaretes paten $\mathrm{M}^{\mathrm{r}}$ Willa ${ }^{a}$ Gybson Cherche wardens Rob ${ }^{t}$ Mylles William Rewe Jem ${ }^{9}$ Elys [\&. I . John Sampson'] Rauf Dyer . \& George Spragye

I John Sampson hathe takyn to kepe thees pselles ffolowyng

[In prym $^{9}$ a pyxe gylt of the gyfte of Syr. Joh donton preste]

Also twoo crewettes parsell gylt]

Also a boxe of sylver \& gylte \& seint Kateryn $\mathrm{w}^{\mathrm{t}}$ in $\mathrm{y}^{\mathrm{t}}$. $]^{1}$

-Thes parsells abovfe wreten the xxvij day of Jully $\mathrm{An}^{\circ} 1536$ | be delyv'd to John Hawkyns to kepe beyng church warden $w^{t}$ wyllym gybson

delyv'ed to $\mathrm{M}^{\mathbf{r}}$ Gybson beyng cherchewarden the twoo grete masers for to sell

Also a boxe of sylv' and gylt that pe pese of the holy crosse was in for to sell

Also a bokyll of sylv' \& gylt for to sell

Also the same day delyv'ed to Thom ${ }^{2}$ s Iagarde Irenmonger . beyng oure paryshe clerke the Chalyce \& the paxe of sylv' \& gylt for to kepe

On the $7 \mathrm{~d}$ of ffebrewr

$a^{\circ} 1548$ and the 2

yer of Kenge edward the 6

Itm Recefed on tow the handes of edwar Rowe | and Robart Dosset cherche wardens of the pares cherche of sent margett paten the lay and yer a for sayde

Itm ij kopes of wyt damasske

Itin j of cafa damasske

Itm iiij of sellke coler gren

sold burtl............champues

Itm j of cheked wellfet

sold Robard toket

Itm 3 of sondre coler for boyes

Itm a weste ment for a cheylde

Itm a wyt wyt.west ment of cafa .

Itm $\mathrm{j}$ of Red wosted

Itm $j$ of Red damasske wet bels

Itm $\mathrm{j}$ of leyans on gren selke - [lyons]

Itm $\mathrm{x}$ of defars and sondre colers [diver's \& sundry colours]

Itm $v$ olde awbes

Itm vj corpos caces

Itm iij] playn cano be stafes [canopy staves]

Itm $\mathrm{j}$ autar clot of blake selke [altar cloth]

Itm xvij staynd clotes for sayntes

Itm iij cross clotes of selke

Itm $\mathrm{x}$ paynted baner clotes

Itm iiij torche stafes

Itm ix stremers | and a crosstafe

\section{7b). \\ (The remaining 12 folios are blank, except an entry on}

The last folio is 208 .

1 All these entries in brackets erased.

2 This entry was inserted when the items above it were erased. 